\title{
Assessment of Motor and Process Skills
}

National Cancer Institute

\section{Source}

National Cancer Institute. Assessment of Motor and Process Skills. NCI Thesaurus. Code C85392.

An observational assessment that is used to measure the quality of a person's activities of daily living (ADL). The quality of the person's ADL performance is assessed by rating the effort, efficiency, safety, and independence of 16 ADL motor and 20 ADL process skill items. 